\title{
INNOVATION STIMULANTS, INNOVATION CAPACITY, AND THE PERFORMANCE OF CAPITAL PROJECTS
}

\author{
Hong Long Chen \\ Department of Business and Management, National University of Tainan, \\ No. 33, Sec. 2, Shu-Lin St., Tainan 700, Taiwan \\ E-mail: along314@mail.nutn.edu.tw
}

Received 07 November 2011; accepted 09 July 2012

\begin{abstract}
Identifying the critical determinants of innovation performance is crucial. However, few studies explore and quantify systematically the relationships between innovation factors and the performance of capital projects. This study of 121 capital projects shows that the relationships among project innovation stimulants, innovation capacity, and project performance are indeed significant. Hierarchical robust regression analyses using a maximum R-square improvement procedure show that technology management has the highest effect on the variation in our project performance data. Validating outof-sample data demonstrates that our optimal model explains $34.42 \%$ of the variation in the performance of capital projects. Ultimately, our findings suggest that project human factors are essential stimulants in innovation performance, which in turn affect the performance of capital projects. Our findings also reveal that the stimulant factors do not have a direct impact on capital project performance, but rather have an indirect impact via project innovation capacity.
\end{abstract}

Keywords: project management, project innovation, project performance, performance measurement, capital project construction, empirical research.

Reference to this paper should be made as follows: Chen, H. L. 2014. Innovation stimulants, innovation capacity, and the performance of capital projects, Journal of Business Economics and Management 15(2): 212-231.

JEL Classification: L74, M11, N65.

\section{Introduction}

Successful innovation management largely depends on identifying the critical determinants of innovation performance. Accordingly, extensive research examines and identifies a wide variety of measures of innovation and the inputs that affect innovation outcomes (e.g., Jassawalla, Sashittal 2002; Miller et al. 2007; Vaccaro et al. 2011).

One recent finding, for example, is that the firms with more slack resources and higher levels of managerial ownership innovate less when firm performance declines (Latham, Braun 2009). Another finding is that the network density of a firm's partners strengthens the influence of technological diversity, which in turn increases the firm's innovation performance (Phelps 2010). 
However, relatively few studies explore innovation from a project perspective. Although several published studies investigate the relationships between innovation and project performance, they primarily examine the relationships between innovation capacity and stimulants (e.g., DeTienne, Koberg 2002; Ebadi, Utterback 1984), between innovation capacity and project performance (e.g., Danneels 2002; Davies, Hobday 2005), or between innovation stimulants and project performance (e.g., Sundström, Zika-Viktorsson 2009; Oke, Idiagbon-Oke 2010).

Furthermore, these published studies principally focus on new product development (NPD) and research and development (R\&D) - despite the fact that capital projects contribute significantly to the growth of economy. The capital projects industry includes both the delivery and the maintenance of facilities (e.g., commercial, institutional, industrial, and residential buildings; as well as transportation, energy, water, sewage, and communication systems).

Our focus is on the delivery process of capital projects. As a result, there appears to be a lack of research that models and quantifies the triangular relationships between innovation factors (stimulants and capacity) and the performance of capital projects to provide management a complete picture of how innovation affects project performance.

The first objective of this study, therefore, is to explore and assess the relationships between innovation factors and the performance of capital projects. The second objective is to quantify systematically the effects of innovation performance on project performance. Both objectives help stakeholders better measure the impact of improved innovation performance on capital projects.

The rest of the paper is organized as follows. "Research background" reviews related studies, "Hypotheses" delineates the test hypotheses, "Research methods" presents the research methodology and describes the sample collection, and "Results" depicts the statistical tests, model-building, and validation. "Discussions" discusses the implications of the research results. "Conclusions" presents the research summary and conclusions.

\section{Research background}

Innovation is often thought of as a change in thought process or a useful application of new inventions or discoveries (McKeown 2008), and it often manifests itself in either a new product, service, procedure, or method (Brady, Söderlund 2008). Innovation has been an essential source of competitive advantage since the beginning of the Industrial Revolution (Prajogo, Ahmed 2006), and existing research (e.g., Prajogo, Ahmed 2006; Sampson 2007) demonstrates a wide range of benefits for corporations that are successful in innovation (e.g., increases in operation efficiency, sales, profitability, and market share). Not surprisingly, numerous researchers and practitioners (e.g., Abbey, Dickson 1983; Sampson 2007) conduct extensive studies to develop innovation models through examining and identifying the key determinants of success in innovation.

Whilst numerous models (e.g., Miller et al. 2007; Motohashi et al. 2012; Ooi et al. 2012; Wu et al. 2008) developed for organizational innovation embody technological and human aspects, one group of scholars (e.g., Adams et al. 2006; Jassawalla, Sashit- 
tal 2002; Prajogo, Ahmed 2006; Prajogo, Sohal 2006) highlights the need to integrate technological aspects with human aspects when modeling innovation performance. The rationale is straightforward: innovation practices should be executed within a suitable environment (i.e., leadership, management, and culture).

For example, Amabile and Conti (1999) show that work environment plays a particularly important role in team creativity based on the study of a large high-technology firm before, during, and after a major downsizing. Shalley et al. (2000) use a survey of 2,200 adults to illustrate how organizations can foster creativity by ensuring that work environments complement the creative requirements of jobs. Jassawalla and Sashittal (2002) note that cultures that highly support innovation, foster teamwork, and promote risk-taking and creative actions positively affect innovation performance. They propose that organizations could develop such cultures by listening to the participants in the NPD processes at high-technology organizations.

Based on a study of 235 professional R\&D workers in large and small technology-based firms, Bommer and Jalajas (2004) note that policies supportive of informal communications affect the extent to which engineers can obtain more valuable information from suppliers, customers, and employees in other departments, which in turn affect innovation performance. Additionally, Elenkov and Manev (2005) show that sociocultural context directly influences leadership and moderates its relationship with organizational innovation based on a sample of 1,774 individuals from 12 European countries. Using a sample of $463 \mathrm{R} \& \mathrm{D}$ alliances in the telecommunications equipment industry, Sampson (2007) finds that an alliance environment contributes far more to firm innovation when technological diversity is moderate, rather than when it is low or high.

Recently, subsequent work based on a sample of 145 firms suggests that service suppliers that retain management control over their intellectual output are more innovative (Leiponen 2008). Based on a longitudinal investigation of 77 telecommunications equipment manufacturers, Phelps (2010) concludes that the network density of a firm's allies and partners strengthens the influence of technological diversity, which in turn increases the firm's innovation performance. More recently, Vaccaro et al. (2012) conclude that smaller, less complex organization environments benefit more from transactional leadership in realizing management innovation. The study is based on a sample of 151 companies.

In addition, Tang et al. (2012) use Tobit-censored normal regression analysis to examine the relationships among executive hubris, organization environment, and firm innovation. Based on a sample of 2,820 manufacturing firms in China and 3,285 U.S. firms in high-tech industries, they conclude that executive hubris positively affects firm innovation performance, but the relationship between executive hubris and firm innovation becomes weaker when the environment is more munificent and complex.

Despite the panoply of studies that use a wide variety of measures to describe innovation outcomes and the input characteristics that affect those outcomes as well as firm performance (e.g., Kessler, Chakrabarti 1996; Tang et al. 2012; Vaccaro et al. 2012), most studies focus on firms engaged in innovation (e.g., Nohria, Gulati 1996; Sampson 2007); relatively few studies explore projects engaged in innovation. 
Further, although some existing studies describe the relationships between innovation and project performance (e.g., Oke, Idiagbon-Oke 2010; Sundström, Zika-Viktorsson 2009), these studies principally focus on examining the relationships between the technological and human aspects of innovation (e.g., DeTienne, Koberg 2002; Ebadi, Utterback 1984), between innovation's technological aspects and project performance (e.g., Davies, Hobday 2005; Kazanjian et al. 2000), or between innovation's human aspects and project performance (e.g., Calamel et al. 2012; Sundström, Zika-Viktorsson 2009; Oke, Idiagbon-Oke 2010).

Furthermore, most published studies primarily focus on NPD and R\&D projects (e.g., Danneels 2002; Sundström, Zika-Viktorsson 2009) - despite the fact that capital projects contribute significant growth to the economy (Chen 2011; Mallick, Mahalik 2010). As a result, there appears to be a lack of research that models and quantifies the triangular relationships between innovation factors (technological aspects and human aspects) and the performance of capital projects, providing management a total picture of how innovation affects project performance.

\section{Hypotheses}

The preceding section critiques existing studies of innovation and project performance. Now the question is: How does project innovation affect the performance of capital projects?

To answer this question, we first examine the relationships between innovation factors and the performance of capital projects. Then, we model and quantify the effects of innovation factors on the performance of capital projects.

To investigate the relationships between innovation factors and the performance of capital projects, we need to develop a series of test hypotheses. A review of literature on innovation suggests that both technological and human aspects affect organizational innovation (e.g., Adams et al. 2006; Jassawalla, Sashittal 2002; Prajogo, Ahmed 2006; Tang et al. 2012). We posit that technological and human issues should not be examined in isolation when modeling the effects of innovation performance on the performance of capital projects. We define the technological factors of innovation performance as innovation capacity concerning the accumulation of knowledge and the creativity and experience of existing and emerging technologies. The human factors of innovation performance that we define as innovation stimulants concern leadership, team-building, communication management, and productive culture.

To articulate the triangular relationships between innovation factors (stimulants and capacity) and the performance of capital projects, we propose three hypotheses:

H1: Stimulant factors of project innovation positively affect the innovation capacity of capital projects.

H2: Stimulant factors of project innovation positively affect the performance of capital projects.

H3: Project innovation capacity positively affects the performance of capital projects. 


\section{Research methods}

\subsection{Participants and procedures}

Of the 500 members of Taiwan's Chinese National Association of General Contractors (CNAGC) that we randomly selected and invited to participate in this research, 121 companies participated - a $24.2 \%$ response rate (CNAGC has over 1,000 members). Of the 121 firms, 24 have less than US\$5 million in revenue; 30 have US\$5 millionUS\$15 million in revenue; 37 have US\$15 million-US\$25 million; and 30 have more than US\$25 million in revenue.

Each of the 121 companies in the sample had a project manager who had just completed a capital project. The 121 capital projects fall into three categories: buildings (69 projects), transportation facilities (22 projects), and industrial facilities (30 projects). Project managers average between one and 26 years of experience; 30 participants had fewer than five years of experience; 51 had between five and 10 years; 33 had between 10 and 20 years; and seven participants had over 20 years of experience.

Surveys collected the data. Prior to the data collection, several experienced researchers and a panel of experts from CNAGC critiqued the questionnaire for structure, readability, clarity, and completeness. These researchers and experts also appraised the extent to which the indicators sufficiently addressed the subject area (Dillman 1978). Based on the feedback from these researchers and experts, the survey instrument was then modified to strengthen its validity.

The final version of the survey questionnaire comprises two sections. The first section, composed of open-ended questions, gathers detailed background information such as annual revenue; project type; project cost, including contract price, budget, contract price for project changes, and actual cost; as well as the project schedule including the contract schedule, scheduled time, contract schedule for project change, and actual schedule.

The second section gathers data for the project innovation variables and measures that data using scales based on a synthesis of literature from the project management, innovation management, group effectiveness, and organizational theory fields. Section two consists of multiple-choice questions in which respondents indicate on a 10-point scale the extent to which certain project variables likely affect the innovation and project performance. Because of space limitations, complete survey questionnaires are available from the authors on request.

\subsection{Measures and analysis}

Cost, time, and performance are the typical measures of project success (Kloppenborg, Opfer 2002). In other words, a project is often considered successful if it finishes within its budget estimate, finishes within its scheduled time frame, and performs as designed (Scott-Young, Samson 2008). Whilst the research literature in project management engages in a fruitful debate over the nature of project performance (Dvir et al. 1998), project performance criteria have become multifaceted. 
For example, Shenhar et al. (2001) use project efficiency, customer benefit, organizational success, and potential benefit to the organization to assess project performance. Yu et al. (2005) develop a value-centered model based on net project execution cost and net project operation value to evaluate project performance. The Project Management Institute (2008) assesses project success with cost, time, quality, and stakeholder satisfaction.

Thus, this study chooses project time, cost, profitability, and customer satisfaction as the criteria for capital project performance. The rationales are straightforward: delays in completion time may turn a promising investment opportunity into an expensive failure (Scott-Young, Samson 2008), cost overrun directly encroaches on profit (Teerajetgul et al. 2009), and project profitability and customer satisfaction ensure business growth and development (Chen 2011).

Further, based on an extensive review of the interdisciplinary literature and in an effort to generate a more parsimonious measurement, we choose widely accepted constructs and their respective key measures of organizational innovation to gauge project innovation stimulants and capacity. Constructs measuring project innovation stimulants that concern project leadership, project team-building, project communication, and culture are Leadership (Lead) and People Management (PM). Those measuring project innovation capacity that relate to the accumulation of project knowledge and project creativity as well as the experience of existing and emerging project technologies are Knowledge Management (KM), Creativity Management (CM), Research and Development $(R \& D)$, and Technology Management (TM). Table 1 lists the taxonomy of measures of these constructs, the means and standard deviations of their respective measures, and the constructs' corresponding Cronbach's $\alpha$ values for the reliability analysis for the 121 sample projects. If not otherwise indicated, all measures use a scale in which 1 is "strongly disagree" and 10 is "strongly agree". High scores suggest good performance; low scores indicate poor performance.

Lead $(\alpha=.92)$ is measured according to a four-item scale (see the respective Variable, Measure, Mean, Standard Deviation, and Cronbach's $\alpha$ columns in Table 1) based on Bart (2002), Linton and Walsh (2004), O’Neil et al. (1998), Prajogo and Ahmed (2006), and Prajogo and Sohal (2006). $P M(\alpha=.97)$ is measured according to a five-item scale (see Table 1) based on Abbey and Dickson (1983), Amabile and Conti (1999), Prajogo and Ahmed (2006), Prajogo and Sohal (2006), and Shalley et al. (2000). $K M(\alpha=.96)$ is measured according to a four-item scale (Table 1) based on Herrera et al. (2010), Miller et al. (2007), Prajogo and Ahmed (2006), Subramaniam and Youndt (2005), Wu et al. (2008), and Youndt et al. (2004).

$C M(\alpha=.96)$ is measured according to a seven-item scale based on Amabile and Conti (1999), Dulaimi et al. (2005), Kratzer et al. (2006), Prajogo and Ahmed (2006), Shalley et al. (2000). TM $(\alpha=.95)$ is measured according to a four-item scale (Table 1) based on Hayes and Wheelwright (1984), Prajogo and Ahmed (2006), Urban and von Hippel (1988). $R \& D(\alpha=.96)$ is measured according to a five-item scale (Table 1) based on Adams et al. (2006), Bessant and Francis (1997), Prajogo and Ahmed (2006), Prajogo and Sohal (2006). 
Table 1. Taxonomy, means, standard deviations, and reliabilities

\begin{tabular}{|c|c|c|c|c|c|}
\hline Variable & Measure & Research Reference & $\begin{array}{c}\text { Mean } \\
\mathrm{N}=121\end{array}$ & $\begin{array}{l}\text { Standard } \\
\text { Deviation }\end{array}$ & $\begin{array}{c}\text { Cronbach's } \\
\alpha\end{array}$ \\
\hline \multirow{4}{*}{ 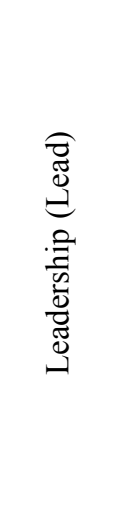 } & $\begin{array}{l}\text { Project leaders share } \\
\text { similar beliefs }\end{array}$ & $\begin{array}{l}\text { O’Neil et al. 1998; } \\
\text { Prajogo, Ahmed 2006; } \\
\text { Miller et al. } 2007\end{array}$ & 7.28 & 1.65 & 0.92 \\
\hline & $\begin{array}{l}\text { Project leaders } \\
\text { encourage learning } \\
\text { and improvement }\end{array}$ & $\begin{array}{l}\text { Linton, Walsh 2004; } \\
\text { Prajogo, Ahmed } 2006\end{array}$ & 7.33 & 1.44 & \\
\hline & $\begin{array}{l}\text { Project leaders } \\
\text { encourage change } \\
\text { and sharing }\end{array}$ & Prajogo, Ahmed 2006 & 5.71 & 1.82 & \\
\hline & Unity of purpose & $\begin{array}{l}\text { Bart 2002; Prajogo, } \\
\text { Ahmed 2006; Prajogo, } \\
\text { Sohal } 2006\end{array}$ & 5.80 & 1.58 & \\
\hline \multirow{5}{*}{ 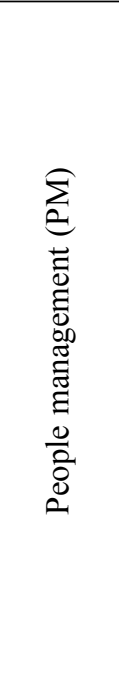 } & $\begin{array}{l}\text { Team member train- } \\
\text { ing and development } \\
\text { exists }\end{array}$ & $\begin{array}{l}\text { Prajogo, Ahmed 2006; } \\
\text { Prajogo, Sohal } 2006\end{array}$ & 6.74 & 1.68 & 0.97 \\
\hline & $\begin{array}{l}\text { Project maintains team } \\
\text { member communica- } \\
\text { tion }\end{array}$ & Prajogo, Ahmed 2006 & 6.21 & 1.67 & \\
\hline & $\begin{array}{l}\text { Team member sat- } \\
\text { isfaction regularly } \\
\text { measured }\end{array}$ & $\begin{array}{l}\text { Prajogo, Ahmed 2006; } \\
\text { Prajogo, Sohal } 2006\end{array}$ & 6.55 & 1.49 & \\
\hline & $\begin{array}{l}\text { Team member training } \\
\text { and multi-skilling used }\end{array}$ & $\begin{array}{l}\text { Prajogo, Ahmed 2006; } \\
\text { Prajogo, Sohal } 2006\end{array}$ & 6.59 & 1.72 & \\
\hline & $\begin{array}{l}\text { Project's work envi- } \\
\text { ronment is positive }\end{array}$ & $\begin{array}{l}\text { Abbey, Dickson 1983; } \\
\text { Amabile, Conti 1999; } \\
\text { Prajogo, Ahmed 2006; } \\
\text { Prajogo, Sohal 2006; } \\
\text { Shalley et al. } 2000\end{array}$ & 6.64 & 1.53 & \\
\hline \multirow{4}{*}{ 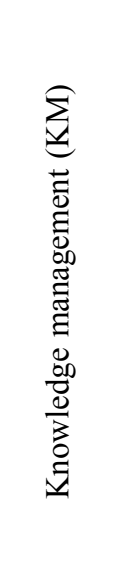 } & $\begin{array}{l}\text { Project intellectual } \\
\text { capital build-up is } \\
\text { important }\end{array}$ & $\begin{array}{l}\text { Prajogo, Ahmed 2006; } \\
\text { Subramaniam, Youndt } \\
\text { 2005; Youndt et al. } \\
2004\end{array}$ & 6.82 & 1.47 & 0.96 \\
\hline & $\begin{array}{l}\text { Regular upgrades in } \\
\text { project-related knowl- } \\
\text { edge and skills }\end{array}$ & $\begin{array}{l}\text { Herrera et al. 2010; } \\
\text { Prajogo, Ahmed } 2006\end{array}$ & 6.86 & 1.62 & \\
\hline & $\begin{array}{l}\text { Company shares and } \\
\text { disseminates project- } \\
\text { related information } \\
\text { and knowledge }\end{array}$ & $\begin{array}{l}\text { Miller et al. 2007; } \\
\text { Prajogo, Ahmed } 2006\end{array}$ & 6.62 & 1.65 & \\
\hline & $\begin{array}{l}\text { Project-related } \\
\text { intellectual assets } \\
\text { managed well }\end{array}$ & $\begin{array}{l}\text { Prajogo, Ahmed 2006; } \\
\text { Wu et al. } 2008\end{array}$ & 6.88 & 1.54 & \\
\hline
\end{tabular}


Continue of Table 1

\begin{tabular}{|c|c|c|c|c|c|}
\hline Variable & Measure & Research Reference & $\begin{array}{c}\text { Mean } \\
\mathrm{N}=121\end{array}$ & $\begin{array}{l}\text { Standard } \\
\text { Deviation }\end{array}$ & $\begin{array}{c}\text { Cronbach's } \\
\alpha\end{array}$ \\
\hline \multirow{7}{*}{ 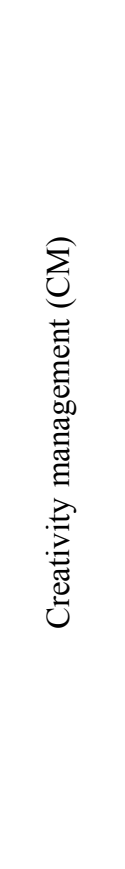 } & $\begin{array}{l}\text { Top management sup- } \\
\text { port for innovative } \\
\text { ideas/solutions is high }\end{array}$ & $\begin{array}{l}\text { Amabile, Conti } 1999 ; \\
\text { Dulaimi et al. } 2005 \text {; } \\
\text { Shalley et al. } 2000\end{array}$ & 6.41 & 1.82 & 0.96 \\
\hline & $\begin{array}{l}\text { Project manager deci- } \\
\text { sion authority is high }\end{array}$ & $\begin{array}{l}\text { Amabile, Conti } 1999 ; \\
\text { Dulaimi et al. } 2005 ; \\
\text { Shalley et al. } 2000\end{array}$ & 6.55 & 1.72 & \\
\hline & $\begin{array}{l}\text { Time and resources } \\
\text { provided for generat- } \\
\text { ing innovative ideas/ } \\
\text { solutions }\end{array}$ & $\begin{array}{l}\text { Amabile, Conti 1999; } \\
\text { Prajogo, Ahmed } 2006\end{array}$ & 6.75 & 1.67 & \\
\hline & $\begin{array}{l}\text { Groups have diverse } \\
\text { skills and communi- } \\
\text { cate openly }\end{array}$ & Prajogo, Ahmed 2006 & 6.47 & 1.57 & \\
\hline & $\begin{array}{l}\text { Cognitive conflicts } \\
\text { moderately high }\end{array}$ & Kratzer et al. 2006 & 6.45 & 1.56 & \\
\hline & $\begin{array}{l}\text { Manager has bottom- } \\
\text { up problem-solving } \\
\text { style }\end{array}$ & Dulaimi et al. 2005 & 6.64 & 1.71 & \\
\hline & $\begin{array}{l}\text { Creativity is rewarded } \\
\text { and recognized }\end{array}$ & $\begin{array}{l}\text { Amabile, Conti 1999; } \\
\text { Prajogo, Ahmed } 2006\end{array}$ & 6.52 & 1.72 & \\
\hline \multirow{4}{*}{ 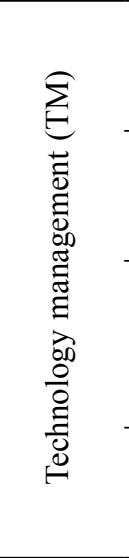 } & $\begin{array}{l}\text { At the leading edge of } \\
\text { project practices/tech- } \\
\text { nologies }\end{array}$ & Urban, von Hippel 1988 & 6.63 & 1.76 & 0.95 \\
\hline & $\begin{array}{l}\text { Evaluating potential } \\
\text { of using new project } \\
\text { technologies/practices }\end{array}$ & $\begin{array}{l}\text { Hayes, Wheelwright } \\
\text { 1984; Prajogo, Ahmed } \\
2006\end{array}$ & 6.66 & 1.49 & \\
\hline & $\begin{array}{l}\text { Acquire project } \\
\text { technological } \\
\text { capabilities in advance } \\
\text { of needs }\end{array}$ & $\begin{array}{l}\text { Hayes, Wheelwright } \\
\text { 1984; Prajogo, Ahmed } \\
2006\end{array}$ & 6.89 & 1.51 & \\
\hline & $\begin{array}{l}\text { Continuously think- } \\
\text { ing of next-generation } \\
\text { technology }\end{array}$ & Prajogo, Ahmed 2006 & 6.71 & 1.63 & \\
\hline \multirow{4}{*}{ 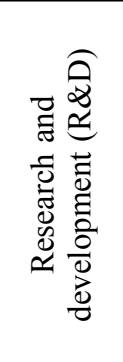 } & $\begin{array}{l}\text { Team education and } \\
\text { confidence are high }\end{array}$ & $\begin{array}{l}\text { Kessler, Chakrabarti } \\
1996\end{array}$ & 6.58 & 1.63 & 0.96 \\
\hline & $\begin{array}{l}\text { Physical resources } \\
\text { adequate }\end{array}$ & Adams et al. 2006 & 6.69 & 1.75 & \\
\hline & $\begin{array}{l}\text { Financial resources } \\
\text { adequate }\end{array}$ & Adams et al. 2006 & 6.38 & 1.70 & \\
\hline & $\begin{array}{l}\text { Tools and systems } \\
\text { adequate }\end{array}$ & Bessant, Francis 1997 & 7.29 & 1.33 & \\
\hline
\end{tabular}


End of Table 1

\begin{tabular}{|c|c|c|c|c|c|}
\hline Variable & Measure & Research Reference & $\begin{array}{c}\text { Mean } \\
\mathrm{N}=121\end{array}$ & $\begin{array}{l}\text { Standard } \\
\text { Deviation }\end{array}$ & $\begin{array}{c}\text { Cronbach's } \\
\alpha\end{array}$ \\
\hline & $\begin{array}{l}\text { R\&D strategically } \\
\text { important }\end{array}$ & $\begin{array}{l}\text { Prajogo, Ahmed 2006; } \\
\text { Prajogo, Sohal } 2006\end{array}$ & 6.69 & 1.69 & \\
\hline 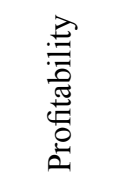 & $\begin{array}{l}\text { Revised profit per- } \\
\text { formance = (revised } \\
\text { contract price }- \text { actual } \\
\text { cost }) / \text { actual cost }\end{array}$ & Hartley, Watt 1981 & 5.50 & 2.94 & \\
\hline $\overrightarrow{0}$ & $\begin{array}{l}\text { Revised cost perfor- } \\
\text { mance }=\text { revised esti- } \\
\text { mated cost/actual cost }\end{array}$ & Anbari 2004 & 5.60 & 2.87 & \\
\hline$\stackrel{\Xi}{\Xi}$ & $\begin{array}{l}\text { Revised time perfor- } \\
\text { mance = revised esti- } \\
\text { mated duration/actual } \\
\text { duration }\end{array}$ & Anbari 2004 & 5.60 & 2.89 & \\
\hline \multirow{10}{*}{ 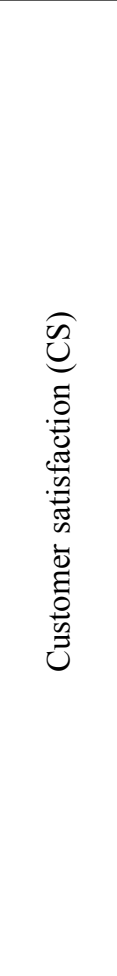 } & $\begin{array}{l}\text { Meets customer } \\
\text { budget estimate }\end{array}$ & $\begin{array}{l}\text { Tohumcu, Karasakal } \\
2010\end{array}$ & 6.89 & 1.67 & 0.97 \\
\hline & $\begin{array}{l}\text { Meets customer } \\
\text { scheduled time frame }\end{array}$ & $\begin{array}{l}\text { Tohumcu, Karasakal } \\
2010\end{array}$ & 7.17 & 1.58 & \\
\hline & Low defect rate & $\begin{array}{l}\text { Tohumcu, Karasakal } \\
2010\end{array}$ & 7.02 & 1.65 & \\
\hline & $\begin{array}{l}\text { Resolves defects } \\
\text { quickly and effectively }\end{array}$ & Ling et al. 2009 & 7.40 & 1.28 & \\
\hline & $\begin{array}{l}\text { Customer complaints } \\
\text { low }\end{array}$ & Luu et al. 2008 & 7.12 & 1.44 & \\
\hline & $\begin{array}{l}\text { Responsiveness to } \\
\text { customer requests/ } \\
\text { complaints }\end{array}$ & $\begin{array}{l}\text { Qureshi et al. 2009; } \\
\text { Tohumcu, Karasakal } \\
2010\end{array}$ & 7.43 & 1.33 & \\
\hline & $\begin{array}{l}\text { Conforms to contract } \\
\text { requirements }\end{array}$ & Ling et al. 2009 & 7.15 & 1.52 & \\
\hline & Courtesy of staff & Ling et al. 2009 & 7.02 & 1.54 & \\
\hline & $\begin{array}{l}\text { Understanding of cus- } \\
\text { tomer's company and } \\
\text { industry }\end{array}$ & Bettencourt et al. 2001 & 7.08 & 1.43 & \\
\hline & $\begin{array}{l}\text { Communication with } \\
\text { the customer is } \\
\text { effective }\end{array}$ & $\begin{array}{l}\text { Chen 2011; Ling et al. } \\
2009\end{array}$ & 7.55 & 1.32 & \\
\hline
\end{tabular}

Finally, Project Performance (PP) is measured on a four-item scale that includes Profitability, Cost, Time, and Customer Satisfaction (CS). Profitability is measured on a one-item scale (see Table 1) based on Hartley and Watt (1981). Cost and Time are both measured according to one-item scale (see Table 1) based on Anbari (2004). CS ( $\alpha=$ 
.97) is measured according to a 10-item scale based on Bettencourt et al. (2001), Chen (2011), Ling et al. (2009), Luu et al. (2008), Qureshi et al. (2009), and Tohumcu and Karasakal (2010).

Principal component analysis reveals that all the factor loadings of the measurement items of Lead, PM, KM, CM, TM, and $R \& D$ are all 0.63 or greater and thus exceed the threshold value of 0.50 (Hair et al. 1998). We therefore include the variables in the innovation performance-measurement model. Principal component analysis also shows that the factor loadings of PP's Time, Cost, Profitability, and CS are 0.57, 0.74, 0.28 , and 0.71 , respectively. (For comparison purpose, percentile ranks categorize time performance on a 10-point scale based on the computed values of Time from the 121 sample projects using the revised estimated duration/actual duration equation in Table 1. The same technique also applies the Cost and Profitability equations in Table 1.) We therefore delete the Profitability measurement item. PP $(\alpha=.73)$ is measured by Time, Cost, and CS.

The methodology to analyze the relationships between innovation factors and performance of capital projects and to quantify the impact of innovation on the performance of capital projects is threefold. First, to test the hypotheses, this study uses the absolute values of the kurtosis indexes to verify normality, followed by maximum likelihood (ML) and asymptotically distribution-free (ADF) estimation methods of structural equation modeling (SEM), respectively, when the data is normally and abnormally distributed.

Second, based on the test results of the hypotheses, this study conducts a hierarchical robust regression analysis using a maximum R-square improvement procedure to obtain the optimum subset of regressor variables. Use of robust regression analysis not only dampens the influence of outlying observations, but also ensures that the forecasts and the model estimation are unbiased when the normality of the residuals is violated (Neter et al. 1996).

Though this study already applies a maximum R-square improvement procedure, which is a very popular method for combating the multicollinearity (Freund, Wilson 1998) that may impair the usefulness of a model's estimated parameters, there is a need to examine if multicollinearity still exists. This study uses incomplete principal-component analysis (Littell, Freund 2000) to detect and rectify the problem of multicollinearity.

Third, this study validates its optimal models using an out-of-sample test. Specifically, this study develops a hypothesis to test whether a significant discrepancy exists in the mean value of the differences between estimated and actual project performance for both the estimation data and the out-of-sample data. To examine the hypothesis, this study uses the Kolmogorov-Smirnov test to verify normality, followed by T-tests and Mann-Whitney tests, respectively, when the data is normally and abnormally distributed. We first use all 121 sample capital projects to test our hypotheses. We then split the sample into two subsamples: the estimation data and the out-of-sample validation data. The estimation data, composed of 61 projects randomly selected from 121 capital projects, are used for model-building. We use the out-of-sample validation data - the remaining 60 projects - to validate the model. 


\section{Results}

\subsection{Results of hypothesis tests}

Figure 1 provides the analysis results of SEM's ML estimation for innovation's effects on the performance of capital projects. This study uses the ML estimation method because the absolute values of the kurtosis indexes are all smaller than 1.24, indicating that the data are normally distributed. The structural model provides an adequate fit to the data, where the model chi-square $\left(\chi^{2}\right)=27.36$, the degree of freedom $(d f)=22$, $\chi^{2} / d f=1.24$, the root mean square error of approximation (RMSEA) $=0.05$, the comparative fit index $(\mathrm{CFI})=0.94$, and the Tucker-Lewis index $(\mathrm{TLI})=0.90$.

As seen in Figure 1, the path coefficients support all but the second hypothesis. Specifically, project stimulant factors positively affect the innovation capacity of capital projects (Hypothesis 1), and project innovation capacity positively affects the performance of capital projects (Hypothesis 3). On the other hand, the rejection of Hypothesis 2 suggests that stimulant factors of project innovation insignificantly affect the performance of capital projects. The test results suggest that project innovation capacity serves as a mediator between innovation stimulants and the performance of capital projects.

To confirm our findings, we compare the fit of our hypothesized model to the alternate model, where the direct path between innovation stimulant and project performance is deleted. The rationale behind this test is straightforward: the alternate model would result in a poorer fit to the data if stimulant factors have a direct impact on project performance.

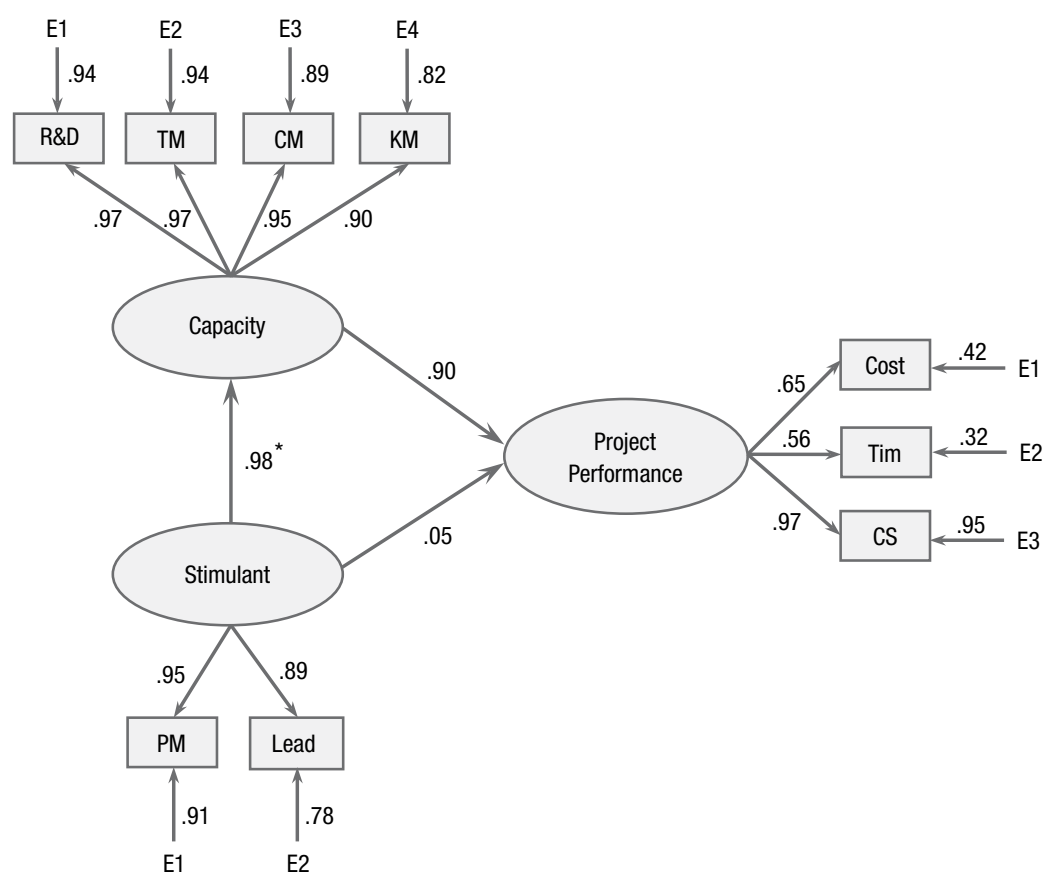

Fig. 1. Innovation's effects on the performance of capital projects 
The alternate model exhibits an almost identical fit to the data, with $\chi^{2}=27.4, d f=23$, $\chi^{2} / d f=1.19, \mathrm{RMSEA}=0.04, \mathrm{CFI}=0.95$, and TLI $=0.92$. This result suggests that deleting the path between stimulant and performance does not make our hypothesized model inferior and therefore verifies that innovation capacity mediates innovation stimulants and the performance of capital projects.

\subsection{Model-building}

As suggested, project innovation capacity (composed of $T M, K M, C M$, and $R \& M$ ) significantly affects the performance of capital projects. Based on the results, this study conducts a series of hierarchical robust regression analyses using a maximum R-squared improvement procedure to develop optimal innovation-effect models from the estimation data of the 61 projects. Table 2 reports the model-building results.

As seen in the table, the optimal innovation-effect model at step 1 (Model 1) includes the $T M$ variable and explains $31.78 \%$ of the variation in the $P P$ data. At step 2, the optimal innovation effect model (Model 2) is composed of $T M$ and $K M$, capable of explaining $33.91 \%$ of the variation in the $P P$ data, which is $2.13 \%$ more than that of Model 1. The optimal models at steps 3 and 4 (Models 3 and 4) are composed of TM,

Table 2. Optimal innovation effect models created with robust regression analysis using a maximum R-squared improvement

\begin{tabular}{|c|c|c|c|c|c|c|c|c|}
\hline \multicolumn{9}{|c|}{ Dependent variable: $P P$} \\
\hline \multirow[t]{2}{*}{ Variables } & \multicolumn{2}{|c|}{ Model 1} & \multicolumn{2}{|c|}{ Model 2} & \multicolumn{2}{|c|}{ Model 3} & \multicolumn{2}{|c|}{ Model 4} \\
\hline & 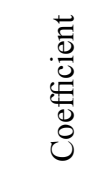 & 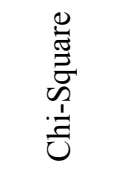 & $\begin{array}{l}\overrightarrow{\overrightarrow{0}} \\
\stackrel{\vec{D}}{0} \\
\stackrel{\vec{E}}{0} \\
0 \\
0\end{array}$ & 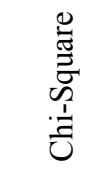 & 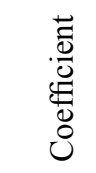 & 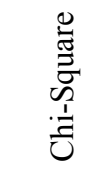 & $\begin{array}{l}\overrightarrow{0} \\
\stackrel{\vec{D}}{0} \\
\stackrel{\rightleftarrows}{0} \\
0 \\
0\end{array}$ & 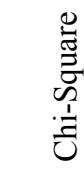 \\
\hline \multicolumn{9}{|c|}{ Step 1} \\
\hline Intercept & 0.46 & 0.22 & 0.36 & 0.14 & 0.35 & 0.12 & 0.37 & 0.71 \\
\hline$T M$ & 0.80 & $28.35^{*}$ & 0.43 & 2.00 & 0.38 & 1.02 & 0.34 & 0.39 \\
\hline \multicolumn{9}{|c|}{ Step 2} \\
\hline$K M$ & & & 0.38 & 1.80 & 0.37 & 1.65 & 0.26 & 0.48 \\
\hline \multicolumn{9}{|c|}{ Step 3} \\
\hline$C M$ & & & & & 0.06 & 0.06 & 0.01 & 0.99 \\
\hline \multicolumn{9}{|c|}{ Step 4} \\
\hline $\mathrm{R} \& \mathrm{D}$ & & & & & & & 0.20 & 0.66 \\
\hline$R^{2}(\%)$ & 31.78 & & 33.91 & & 33.91 & & 34.42 & \\
\hline Changes of $R^{2}(\%)$ & & & 2.13 & & 0.00 & & 0.51 & \\
\hline The White test & & 2.10 & & 5.12 & & 9.56 & & 11.23 \\
\hline
\end{tabular}

Notes: ${ }^{*} \mathrm{p}<0.05 ; * * \mathrm{p}<.01 ; * * * \mathrm{p}<.001$. 
$K M$, and $C M$, and $T M, K M, C M$, and $R \& D$, respectively. The corresponding R-squares of Models 3 and 4 are $33.91 \%$ and 34.42\%, suggesting that Model 4 is the optimum model among Models 1 to 4.

The bottom of Table 2 shows the chi-square values of the White test (White 1980) for Models 1 to 4. The White test establishes whether the residual variance of a variable in a regression model is constant (homoscedasticity) or not (heteroskedasticity). Diagnostics for heteroskedasticity in regression models are essential because heteroskedasticity leads to inefficient parameter and covariance-matrix estimates. As seen in the table, the chisquare value for the White test of Model 4 is 11.23 , and the associated $p$-value is larger than 0.05 , suggesting the acceptance of the null hypothesis of no heteroskedasticity in the residuals at the 0.05 level.

Further, multicollinearity, in which two or more independent variables in a multivariate regression model are highly correlated, may impair the usefulness of the model's estimated parameters by inflating their variances (Freund, Wilson 1998). Hence, this study uses the eigenvalues (Freund, Wilson 1998), the variance of principal-component regression analysis, to determine if the effects of multicollinearity are present in the model.

The multicollinearity diagnostics of Model 4 are in the left-hand side Table 3, where the "Condition Number" column, the square root of the ratio of the largest to smallest eigenvalue, indicates the degree of near-linear dependencies. Eigenvalues have condition numbers larger than 30, and variables with variation proportions greater than 0.5 for each of these eigenvalues are involved in the near-linear dependency (Belsley et al. 1980). As seen in the table, although the $K M$ and $R \& D$ variables of the fourth eigenvalue have respective variation proportions of 0.70 and 0.84 , the fourth eigenvalue has a condition number of 7.33 - smaller than 30 . Consequently, multicollinearity does not exist in the model.

Table 3. Multicollinearity diagnostics, Kolmogorov-Smirnov, and Mann-Whitney tests of Model $4^{\text {a }}$

\begin{tabular}{|c|c|c|c|c|c|c|c|c|c|c|c|c|}
\hline \multirow[b]{3}{*}{ 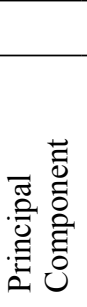 } & \multicolumn{6}{|c|}{ Multicollinearity Diagnostics } & \multicolumn{6}{|c|}{ Kolmogorov-Smirnov and Mann-Whitney Tests } \\
\hline & \multirow[b]{2}{*}{ 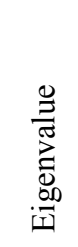 } & \multirow[b]{2}{*}{ 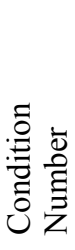 } & \multicolumn{4}{|c|}{ Proportion of Variation } & \multirow[b]{2}{*}{$\begin{array}{l}\stackrel{0}{0} \\
\vdots \\
\stackrel{0}{0}\end{array}$} & \multirow[b]{2}{*}{ 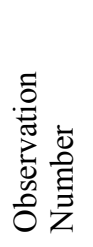 } & \multirow[b]{2}{*}{ 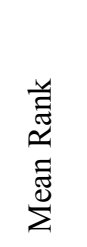 } & \multirow[b]{2}{*}{ 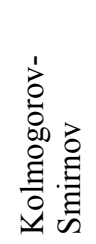 } & \multirow{2}{*}{ 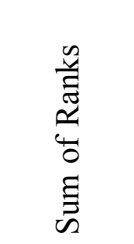 } & \multirow{2}{*}{ 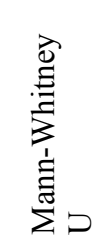 } \\
\hline & & & $T M$ & $K M$ & $C M$ & $R \& D$ & & & & & & \\
\hline 1 & 3.59 & 1.00 & 0.01 & 0.01 & 0.01 & 0.01 & $\mu_{E|P P-\hat{P} P|}$ & 61 & 55.15 & $0.13^{*}$ & 3364.00 & 1473.00 \\
\hline 2 & 0.23 & 3.92 & 0.01 & 0.23 & 0.55 & 0.01 & $\mu_{O S|P P-\hat{P} P|}$ & 60 & 66.95 & 0.08 & 4017.00 & \\
\hline 3 & 0.12 & 5.64 & 0.96 & 0.06 & 0.12 & 0.14 & & & & & & \\
\hline 4 & 0.07 & 7.33 & 0.027 & 0.70 & 0.32 & 0.84 & & & & & & \\
\hline
\end{tabular}

${ }^{\text {a }}$ Model $4=0.37+0.34 T M+0.26 K M+0.01 C M+0.20 R \& D$, where $R^{2}=34.42 \%$.

Notes: ${ }^{*} \mathrm{p}<0.05$; ** $\mathrm{p}<.01$; *** $\mathrm{p}<.001$. 


\subsection{Model validation}

This study validates its optimal innovation-effect model (Model 4) using an out-ofsample test. We use Model 4 to estimate the performance of the 60 out-of-sample capital projects, which we then compare to the 60 projects' actual performance. To determine conclusively whether Model 4 (developed from the estimation data for the 61 capital projects using the proposed estimation method) provides equal estimation power for the out-of-sample data, we form the hypothesis:

$\mathbf{H}_{\mathbf{0}}: \mu_{E|P P-\hat{P} P|}=\mu_{O S|P P-\hat{P} P|}$,

$\mathbf{H}_{\mathbf{a}}: \mu_{E|P P-\hat{P} P|} \neq \mu_{O S|P P-\hat{P} P|}$

where $\mu_{E|P P-\hat{P} P|}$ is the absolute average value of the differences between estimated and actual project performance for the 61 estimation projects, and $\mu_{O S|P P-\hat{P} P|}$ is the absolute average value of the differences between estimated and actual project performance for the 60 out-of-sample projects.

The hypothesis examines whether a significant discrepancy exists in the mean value of the differences between the estimated and actual project performance of the 61 estimation projects and the 60 out-of-sample projects. If no significant discrepancy exists, we can confidently claim that our optimal innovation-effect model (Model 4) explains $34.42 \%$ of the variation in project performance.

The right-hand side of Table 3 shows the results of the Kolmogorov-Smirnov and MannWhitney tests. We use the Mann-Whitney test because the significant 0.13 value from the Kolmogorov-Smirnov sets suggests that the data sets of $\mu_{E|P P-\hat{P} P|}$ are abnormally distributed. The sample data is also unpaired (there are 61 estimation projects versus 60 out-of-sample projects).

As the right-hand side of Table 3 shows, the Mann-Whitney U is 1473.00 and the associated $p$-value is larger than 0.05 , confirming an insignificant discrepancy. We therefore accept the null hypothesis, implying that no significant discrepancy exists in the mean value of the differences between the estimated and actual project performance of the 61

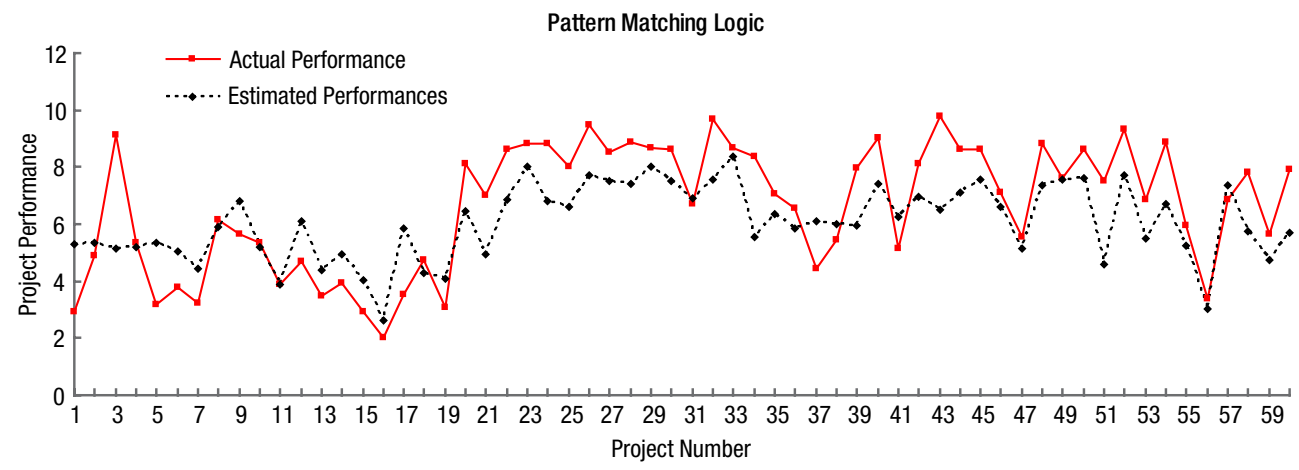

Fig. 2. Plots of the actual versus fitted values of Model 4 for the 60 out-of-sample projects 
estimation projects and the 60 out-of-sample projects in the optimal innovation-effect model (Model 4). Figure 2 plots the actual project performance against the estimated project performance for the 60 out-of-sample projects in Model 4.

\section{Discussions}

This study examines and models the triangular relationships between innovation factors (stimulants and capacity) and the performance of capital projects. Drawing on the literature in innovation management (e.g., Adams et al. 2006; Jassawalla, Sashittal 2002; Prajogo, Ahmed 2006; Prajogo, Sohal 2006), we posit that innovation stimulants and capacity should not be examined in isolation when modeling the effects of innovation performance on the performance of capital projects.

The results of hypothesis tests show that project stimulant factors positively affect the innovation capacity of capital projects, and project innovation capacity positively affects the performance of capital projects. However, stimulant factors of project innovation insignificantly affect the performance of capital projects. In fact, drawing on the structural relationships shown in Figure 1, project innovation capacity serves as a mediator between innovation stimulants and the performance of capital projects. In other words, the stimulant factors do not have a direct impact on capital project performance but rather have an indirect impact realized through project innovation capacity.

Our test results reported here provide a comprehensive framework for analyzing the relationship between project practices and innovation performance. As mentioned, most prior research on project innovation focuses on examining the relationships between innovation capacity and stimulants, between innovation capacity and project performance, or between innovation stimulants and project performance. From a managerial perspective, constraining findings of one or another of these studies might be potentially misleading.

For example, based on the findings of the relationship between innovation capacity and project performance, this study quantifies the effects of innovation performance on project performance using a series of hierarchical robust regression analyses. The optimal innovation-effect model, composed of $T M, K M, C M$, and $R \& D$, explains $34.42 \%$ of the variation in project performance. In other words, this model indicates that whilst a capital project may improve innovation by $T M, K M, C M$, and $R \& D$, the innovation also improves the performance of the capital project by $34.42 \%$. This indication may mistakenly suggest that having excellent technology, R\&D, knowledge, and creativity management is sufficient for accomplishing high project performance.

In sum, our findings suggest that project innovation capacity positively affects the performance of capital projects, and project stimulant factors are fundamental enablers that affect innovation performance and, by extension, the performance of capital projects. Therefore, in order to create innovative projects, project leaders need to build project environments that foster leadership, team-building, communication, and a productive culture for innovation. Such environments provide momentum that motivates project team members to innovate. More important, such environments allow project-based organizations to leverage their innovative capacity to deliver innovative outcomes and project performance. 


\section{Conclusions}

Extensive research in the innovation-management field examines and identifies a wide variety of measures that describe innovation outcomes and the inputs that affect those outcomes; however, relatively little research explores innovation from a project perspective. Although several published studies delineate the relationships between innovation and project performance, most studies concentrate on examining the relationships between innovation capacity and stimulants, between innovation capacity and project performance, or between innovation stimulants and project performance. Further, these studies primarily focus on NPD and R\&D projects - despite the fact that the capital projects industry also contributes significantly to the growth of economy.

This study develops an innovation performance-measurement model for capital projects by incorporating technological factors (capacity) and human factors (stimulants). The results show that innovation capacity mediates the relationship between innovation stimulants and innovation performance (and thus, by extension, project performance) that is consistent with prior research at the firm level. This study reclassifies creativity and knowledge management into the technological aspect (capacity) and extends the findings to the project level.

This study performs hierarchical robust regression analyses using a maximum R-squared improvement procedure to develop optimal innovation-effect models that are based on capacity variables. Out-of-sample validation demonstrates that our optimal model explains $34.42 \%$ of the variation in project performance. This result in turn implies that as the innovation performance of a capital project improves, the project's performance improves by $34.42 \%$.

In conclusion, this study clarifies and explains the relationship between the technological and human aspects of innovation performance at the project level, and it offers managers a practical way to measure the impact of project innovation performance on project performance. As an extension of this research, a study of the longitudinal relationships between project innovation and performance throughout the project-delivery process would benefit decision-making, management, and project control.

\section{Acknowledgment}

We would like to thank the Taiwan National Science Council for financially supporting this research.

\section{References}

Abbey, A.; Dickson, J. W. 1983. R\&D work climate and innovation in semiconductors, Academy of Management Journal 26(2): 362-368. http://dx.doi.org/10.2307/255984

Adams, R.; Bessant, J.; Phelps, R. 2006. Innovation management measurement: a review, International Journal of Management Reviews 8(1): 21-47.

http://dx.doi.org/10.1111/j.1468-2370.2006.00119.x

Amabile, T. M.; Conti, R. 1999. Changes in the work environment for creativity during downsizing, Academy of Management Journal 42(6): 630-640. http://dx.doi.org/10.2307/256984 
Anbari, F. T. 2004. Earned value project management method and extensions, IEEE Engineering Management Review 32(3): 97-97. http://dx.doi.org/10.1109/EMR.2004.25113

Bart, C. K. 2002. Product innovation charters: mission statements for new products, R\&D Management 32(1): 23-34. http://dx.doi.org/10.1111/1467-9310.00236

Belsley, D. A.; Kuh, E.; Welsch, R. E. 1980. Regression diagnostics. New York: John Wiley \& Son. http://dx.doi.org/10.1002/0471725153

Bettencourt, L. A.; Gwinner, K. P.; Meuter, M. L. 2001. A comparison of attitude, personality, and knowledge predictors of service-oriented organizational citizenship behaviors, Journal of Applied Psychology 86(1): 29-41. http://dx.doi.org/10.1037/0021-9010.86.1.29

Bessant, J.; Francis, D. 1997. Implementing the new product development process, Technovation 17(4): 189-197. http://dx.doi.org/10.1016/S0166-4972(97)84690-1

Bommer, M.; Jalajas, D. S. 2004. Innovation sources of large and small technology-based firms, IEEE Transactions of Engineering Management 51(1): 13-18.

http://dx.doi.org/10.1109/TEM.2003.822462

Brady, T.; Söderlund, J. 2008. Projects in innovation, innovation in projects selected papers from the IRNOP VIII conference, International Journal of Project Management 26(5): 465-468.

http://dx.doi.org/10.1016/j.ijproman.2008.06.007

Calamel, L.; Defélixa, C.; Picqd, T.; Retour, D. 2012. Inter-organisational projects in French innovation clusters: the construction of collaboration, International Journal of Project Management 30(1): 48-59.

Chen, H. L. 2011. An empirical examination of project contractors' supply-chain cash flow performance and owners' payment patterns, International Journal of Project Management 29(5): 604-614. http://dx.doi.org/10.1016/j.ijproman.2010.04.001

Danneels, E. 2002. The dynamics of product innovation and firm competencies, Strategic Management Journal 23(12): 1095-1121. http://dx.doi.org/10.1002/smj.275

Davies, A.; Hobday, M. 2005. The business of projects: managing innovation in complex products and systems. Cambridge: Cambridge University Press.

http://dx.doi.org/10.1017/CBO9780511493294

DeTienne, D. R.; Koberg, C. S. 2002. The impact of environmental and organizational factors on discontinuous innovation within high-technology industries, IEEE Transactions on Engineering Management 49(4): 352-364. http://dx.doi.org/10.1109/TEM.2002.806719

Dillman, D. A. 1978. Mail and telephone surveys: the total design method. New York: John Wiley \& Sons.

Dulaimi, M. F.; Nepal, M. P.; Park, M. 2005. A hierarchical structural model of assessing innovation and project performance, Construction Management and Economics 23(6): 565-577. http://dx.doi.org/10.1080/01446190500126684

Dvir, D.; Lipovetsky, S.; Shenhar, A.; Tishler, A. 1998. In search of project classification: a nonuniversal approach to project success factors, Research Policy 27: 915-935.

http://dx.doi.org/10.1016/S0048-7333(98)00085-7

Ebadi, Y. M.; Utterback, J. M. 1984. The effects of communication on technological innovation, Management Science 30 (5): 572-586. http://dx.doi.org/10.1287/mnsc.30.5.572

Elenkov, D. S.; Manev, I. M. 2005. Top management leadership and influence on innovation: the role of sociocultural context, Journal of Management 31(3): 381-402.

http://dx.doi.org/10.1177/0149206304272151

Freund, R. J.; Wilson, W. J. 1998. Regression analysis: statistical modeling of a response variable. CA: Academic Press.

Hair, J. F.; Anderson, R. E.; Tatham, R. L.; Black, W. C. 1998. Multivariate data analysis. Upper Saddle River, NJ: Prentice-Hall International Inc. 
Hartley, K.; Watt, P. A. 1981. Profits, regulation and the UK aerospace industry, The Journal of Industrial Economics 29(4): 413-428. http://dx.doi.org/10.2307/2098255

Hayes, R.; Wheelwright, S. 1984. Restoring our competitive edge: competing through manufacturing. New York: John Wiley.

Herrera, L.; Muñoz-Doyague, M. F.; Nieto, M. 2010. Mobility of public researchers, scientific knowledge transfer, and the firm's innovation process, Journal of Business Research 63(5): 510-518. http://dx.doi.org/10.1016/j.jbusres.2009.04.010

Jassawalla, A. R.; Sashittal, H. C. 2002. Cultures that support product-innovation processes, Academy of Management Executive 16(3): 42-54. http://dx.doi.org/10.5465/AME.2002.8540307

Kazanjian, R. K.; Drazin, R.; Glynn, M. A. 2000. Creativity and technological learning: the roles of organization architecture and crisis in large-scale projects, Journal of Engineering and Technology Management 17 (3--4): 273-298.

Kessler, E. H.; Chakrabarti, A. K. 1996. Innovation speed: a conceptual model of context, antecedents, and outcomes, Academy of Management Review 21(4): 1143-1191.

Kloppenborg, T. J.; Opfer, W. A. 2002. The current state of project management research: trends, interpretations, and predictions, Project Management Journal 33(2): 5-18.

Kratzer, J.; Leenders, R. T. A. J.; van Engelen, J. M. L. 2006. Team polarity and creative performance in innovation teams, Creativity and Innovation Management 15(1): 96-104.

http://dx.doi.org/10.1111/j.1467-8691.2006.00372.x

Latham, S. F.; Braun, M. 2009. Managerial risk, innovation, and organizational decline, Journal of Management 35(2): 258-281. http://dx.doi.org/10.1177/0149206308321549

Leiponen, A. 2008. Control of intellectual assets in client relationships: implications for innovation, Strategic Management Journal 29(13): 1371-1394. http://dx.doi.org/10.1002/smj.715

Ling, F. Y. Y.; Low, S. P.; Wang, S. Q.; Lim, H. H. 2009. Key project management practices affecting Singaporean firms' project performance in China, International Journal of Project Management 27(1): 59-71. http://dx.doi.org/10.1016/j.ijproman.2007.10.004

Linton, J. D.; Walsh, S. T. 2004. Integrating innovation and learning curve theory: an enabler for moving nanotechnologies and other emerging process technologies into production, $R \& D$ Management 34(5): 517-526. http://dx.doi.org/10.1111/j.1467-9310.2004.00359.x

Littell, R. C.; Freund, R. J. 2000. SAS system for regression. Cary: SAS Institute Inc.

Luu, V. T.; Kim, S. Y.; Huynh, T. A. 2008. Improving project management performance of large contractors using benchmarking approach, International Journal of Project Management 26(7): 758-769. http://dx.doi.org/10.1016/j.ijproman.2007.10.002

Mallick, H.; Mahalik, M. K. 2010. Constructing the economy: the role of construction sector in India's growth, Journal of Real Estate Finance and Economics 40(3): 368-384.

http://dx.doi.org/10.1007/s11146-008-9137-z

McKeown, M. 2008. The truth about innovation. London: Prentice Hall.

Miller, D. J.; Fern, M. J.; Cardinal, L. B. 2007. The use of knowledge for technological innovation within diversified firms, Academy of Management Journal 50(2): 308-326.

http://dx.doi.org/10.5465/AMJ.2007.24634437

Motohashi, K.; Lee, D. R.; Sawng, Y. W.; Kim, S. H. 2012. Innovative converged service and its adoption, use and diffusion: a holistic approach to diffusion of innovations, combining adoptiondiffusion and use-diffusion paradigms, Journal of Business Economics and Management 13(2): 308-333. http://dx.doi.org/10.3846/16111699.2011.620147

Neter, J.; Kutner, M. H.; Nachtsheim, C. J.; Wasserman, W. 1996. Applied linear statistical models. Boston: McGraw-Hill. 
Nohria, N.; Gulati, R. 1996. Is slack good for innovation?, Academy of Management Journal 39(5): 1245-1264. http://dx.doi.org/10.2307/256998

Oke, A.; Idiagbon-Oke, M.; 2010. Communication channels, innovation tasks and NPD project outcomes in innovation-driven horizontal networks, Journal of Operations Management 28(5):442-453. http://dx.doi.org/10.1016/j.jom.2010.01.004

O’Neil, H. M.; Pouder, R. W.; Buchholtz, A. K. 1998. Patterns in the diffusion of strategies across organizations: insights from the innovation diffusion literature, Academy of Management Review 23(1): 98-114.

Ooi, K. B.; Lin, B.; Teh, P. L.; Chong, A. Y. L. 2012. Does TQM support innovation performance in Malaysia's manufacturing industry?, Journal of Business Economics and Management 13(2): 366-393. http://dx.doi.org/10.3846/16111699.2011.620155

Phelps, C. C. 2010. A longitudinal study of the influence of alliance network structure and composition on firm exploratory innovation, Academy of Management Journal 53(4): 890-913.

http://dx.doi.org/10.5465/AMJ.2010.52814627

Prajogo, D. I.; Ahmed, P. K. 2006. Relationships between innovation stimulus, innovation capacity, and innovation performance, $R \& D$ Management 36(5): 499-515.

http://dx.doi.org/10.1111/j.1467-9310.2006.00450.x

Prajogo, D. I.; Sohal, A. S. 2006. The integration of TQM and technology/R\&D management in determining quality and innovation performance, Omega-International Journal of Management Science 34(3): 296-312. http://dx.doi.org/10.1016/j.omega.2004.11.004

Project Management Institute. 2008. A guide to the project management body of knowledge (PMBOK Guide). 4th ed. Newtown Square, PA: Project Management Institute.

Qureshi, T. M.; Warraich, A. S.; Hijazi, S. T. 2009. Significance of project management performance assessment (PMPA) model, International Journal of Project Management 27(4): 378-388. http://dx.doi.org/10.1016/j.ijproman.2008.05.001

Sampson, R. C. 2007. R\&D alliances and firm performance: the impact of technological diversity and alliance organization on innovation, Academy of Management Journal 50(2): 364-386. http://dx.doi.org/10.5465/AMJ.2007.24634443

Scott-Young, C.; Samson, D. 2008. Project success and project team management: evidence from capital projects in the process industries, Journal of Operations Management 26(6): 749-766. http://dx.doi.org/10.1016/j.jom.2007.10.006

Shalley, C. E.; Gilson, L. L.; Blum, T. C. 2000. Matching creativity requirements and the work environment: effects on satisfaction and intentions to leave, Academy of Management Journal 43(2): 215-223. http://dx.doi.org/10.2307/1556378

Shenhar, A. J.; Dvir, D.; Levy, O.; Maltz, A. C. 2001. Project success: a multidimensional strategic concept, Long Range Planning 34(6): 699-725.

http://dx.doi.org/10.1016/S0024-6301(01)00097-8

Subramaniam, M.; Youndt, M. A. 2005. The influence of intellectual capital on the types of innovative capabilities, Academy of Management Journal 48(3): 450-463.

http://dx.doi.org/10.5465/AMJ.2005.17407911

Sundström, P.; Zika-Viktorsson, A. 2009. Organizing for innovation in a product development project: combining innovative and result oriented ways of working - a case study, International Journal of Project Management 27(8): 745-753. http://dx.doi.org/10.1016/j.ijproman.2009.02.007

Tang, Y.; Li, J. T.; Yang, H. 2012. What I see, what I do: how executive hubris affects firm innovation, Journal of Management. http://dx.doi.org/10.1177/0149206312441211

Teerajetgul, W.; Chareonngam, C.; Wethyavivorn, P. 2009. Key knowledge factors in Thai construction practice, International Journal of Project Management 27(8): 833-839.

http://dx.doi.org/10.1016/j.ijproman.2009.02.008 
Tohumcu, Z.; Karasakal, E, 2010. R\&D project performance evaluation with multiple and interdependent criteria, IEEE Transactions on Engineering Management 57(4): 620-633. http://dx.doi.org/10.1109/TEM.2009.2036159

Urban, G. L.; von Hippel, E. 1988. Lead user analyses for the development of new industrial products, Management Science 34(5): 569-582. http://dx.doi.org/10.1287/mnsc.34.5.569

Vaccaro, A.; Brusoni, S.; Veloso, F. M. 2011. Virtual design, problem framing and innovation: an empirical study in the automotive industry, Journal of Management Studies 48(1): 99-122. http://dx.doi.org/10.1111/j.1467-6486.2010.00939.x

Vaccaro, I. G.; Jansen, J. J. P.; Van Den Bosch, F. A. J.; Volberda, H. W. 2012. Management innovation and leadership: the moderating role of organizational size, Journal of Management Studies 49(1): 28-51. http://dx.doi.org/10.1111/j.1467-6486.2010.00976.x

White, H.; 1980. A heteroskedasticity-consistent covariance matrix estimator and a direct test for heteroskedasticity, Econometrica 48(4): 817-838. http://dx.doi.org/10.2307/1912934

Wu, W. Y.; Chang, M. L.; Chen, C. W. 2008. Promoting innovation through the accumulation of intellectual capital, social capital, and entrepreneurial orientation, $R \& D$ Management 38(3): 265-277.

Youndt, M. A.; Subramaniam, M.; Snell, S. A. 2004. Intellectual capital profiles: an examination of investments and returns, Journal of Management Studies 41(2): 335-361.

http://dx.doi.org/10.1111/j.1467-6486.2004.00435.x

Yu, A. G.; Flett, P. D.; Bowers, J. A. 2005. Developing a value-centred proposal for assessing project success, International Journal of Project Management 23(6): 428-436.

http://dx.doi.org/10.1016/j.ijproman.2005.01.008

Hong Long CHEN (PhD, University of Florida) is a Professor in the department of Business and Management at the National University of Tainan, Taiwan. His research interests are project finance, corporate finance, performance management, and supply chain management. He is a reviewer of several prestigious journals, such as the IEEE Transactions on Engineering Management, International Journal of Project Management, Supply Chain Management: An International Journal, International Journal of Production Economics, Journal of Management in Engineering, Journal of Construction Engineering and Management, and Construction Management and Economics. He is also a member of the editorial board of International Journal of Information Technology Project Management. 